\title{
Posterior reversible encephalopathy syndrome and pregnancy: a Moroccan retrospective study of a patient's oligo series
}

\author{
Aboubakr Benjilany*, Jaouad Kouach \\ Department of Obstetrics and Gynecology, Military Hospital of Instruction Mohamed V, Rabat, Morocco \\ Received: 27 July 2021 \\ Accepted: 04 September 2021

\section{*Correspondence:} \\ Dr. Aboubakr Benjilany, \\ E-mail: benjilany.ab@gmail.com \\ Copyright: ( ) the author(s), publisher and licensee Medip Academy. This is an open-access article distributed under \\ the terms of the Creative Commons Attribution Non-Commercial License, which permits unrestricted non-commercial \\ use, distribution, and reproduction in any medium, provided the original work is properly cited.
}

\begin{abstract}
Posterior reversible encephalopathy syndrome (PRES) is an entity combining reversible central nervous system damages with characteristic magnetic resonance imaging (MRI) brain imaging, it can occur in peripartum regardless of any preexisting pathology. PRES in peripartum is a poorly understood phenomenon. Early diagnosis and management are essential to prevent irreversible neurological sequelae. We report 6 cases series of PRES, collected at obstetrics and gynecology department of the military hospital Mohamed V in Rabat, between 2000 and 2019, in order to describe and analyze epidemiological, clinical, paraclinical and therapeutic aspects. Average age was 27 years old. Found symptoms were: high blood pressure, seizures, headaches, visual disturbances, consciousness disorders, vivid osteotendinous reflexes, vertigo, nausea and vomiting. Associated complications were status epilepticus, eclampsia, haemolysis, elevated liver enzymes, low platelet count (HELLP) syndrome and acute lung edema. Radiologically, found lesions are suggestive of PRES. After management, evolution was favorable in all patients.
\end{abstract}

Keywords: PRES, Pregnancy, Retrospective studies, Morocco

\section{INTRODUCTION}

Posterior reversible encephalopathy syndrome (PRES) is a clinical and radiological entity that has been revealed rather recently, it combines a reversible damage of central nervous system with characteristic brain imaging. Physiopathology remains a source of disagreement. It is a unique neurological entity that can occur in peripartum, regardless of any pre-existing pathology. Diagnosis calls for an evocative context, a characteristic symptomatology, a typical MRI appearance with a clinical and radiological reversibility.

\section{CASE SERIES}

We report a 6 cases retrospective series of PRES, collected in department of obstetrics and gynecology and managed in collaboration with both departments of intensive care and neurology in the military hospital of instruction Mohamed V Rabat, between 2000 and 2019, In order to describe and analyze epidemiological, clinical, paraclinical, therapeutic and evolutionary aspects of this pathological entity.

Analyzed data were extracted from patients' clinical report. PRES diagnosis is retained in front of a characteristic symptomatology, an evocative context, a typical aspect of MRI with a clinical and radiological reversibility. We eliminated all incomplete reports, patients without a sure PRES diagnosis, and patients lost to follow-up.

All data was collected on operating sheet as follows: 1 . Age, 2. Medical history, 3. Gynecological and obstetrical history, 4. Evolution of pregnancy and gestational age, 5. Clinical parameters: Onset of childbirth signs, temperature $\left({ }^{\circ} \mathrm{C}\right)$, Systolic blood pressure (SBP), diastolic blood pressure (DBP) in $\mathrm{mm} \mathrm{Hg}$, lower limbs edema, proteinuria, Neurological signs: Consciousness status assessed by Glasgow score, Headache (onset time), Convulsive seizures and/or status epilepticus existence (onset time, and blood pressure levels during), Presence or 
not of neurological deficit, Osteotendinous reflexes examination, Visual disturbances existence, 6. Neuroimaging (Brain (CT) and/ MRI), 7. Biological data, 8. Electroencephalogram, 9. Associated complications, 10. Therapeutic and obstetric care, 11. Immediate evolution and control data and 12. Newborn's state.

Obtained information have been compiled in Table 1.
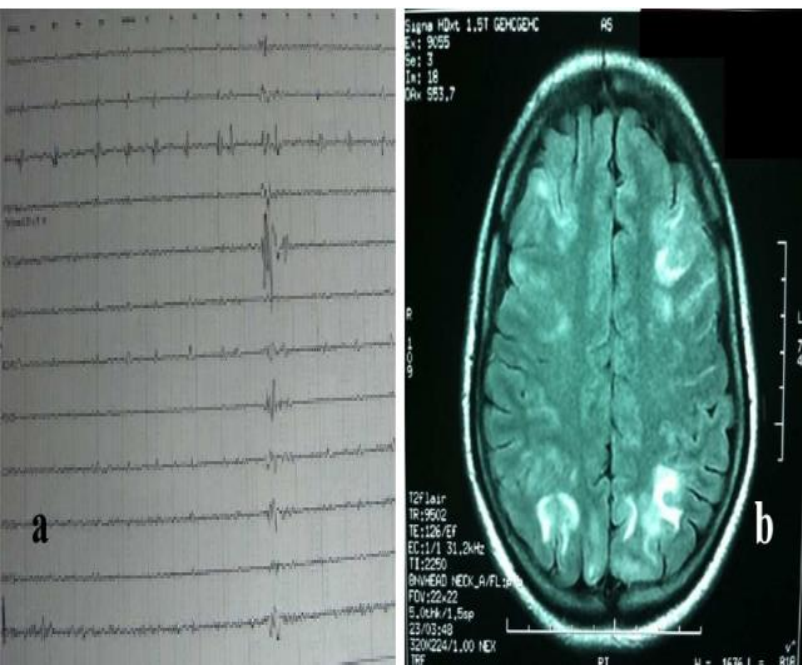

Figure 1 (A and B): Electroencephalogram: a diffuse paroxysmal activity for short time and brain MRI, axial section, FLAIR sequence: hypersignals of the subcortical white matter at the frontal and bilateral parietal areas.

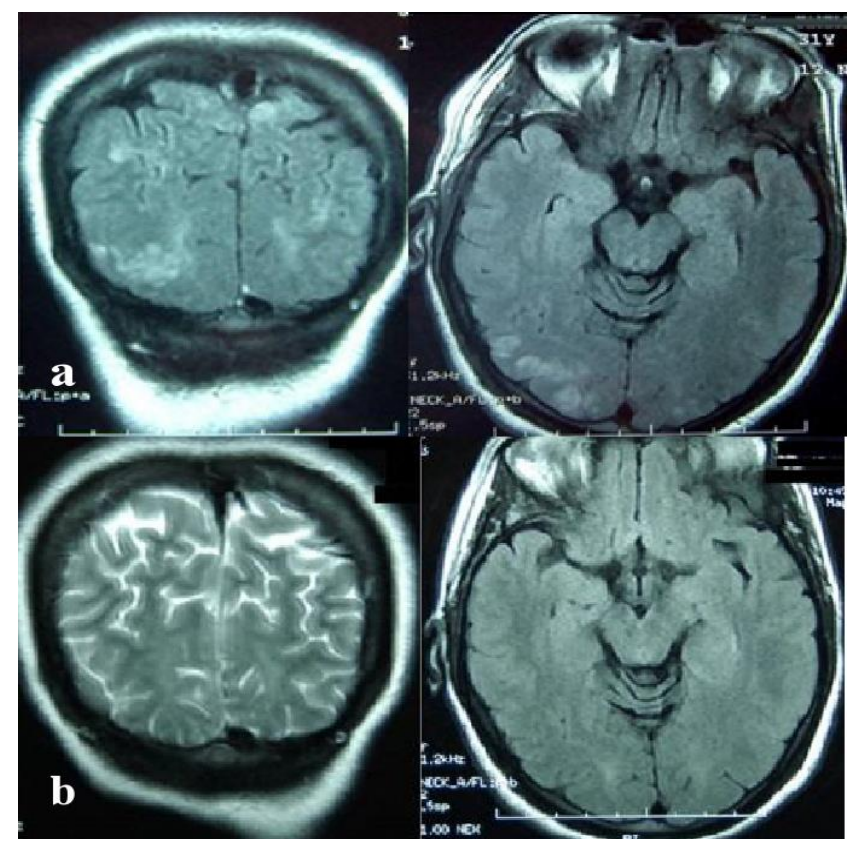

Figure 2 (A and B): Brain magnetic resonance imaging (MRI), axial and coronal section, FLAIR sequence: bilateral and asymmetric corticosubcortical hypersignals, in parieto-occipital area and the 2 months brain MRI control: complete resolution of the brain damages.

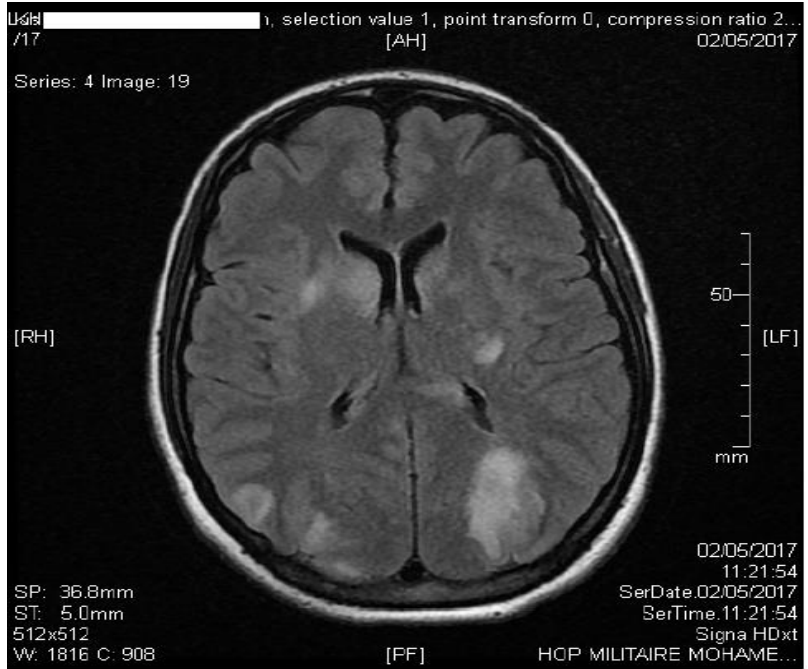

Figure 3: Brain MRI, axial section, FLAIR sequence: Bilateral and asymmetric cortico-subcortical hypersignals, in parietal, capsulo-lenticulars and caudate nuclei heads.

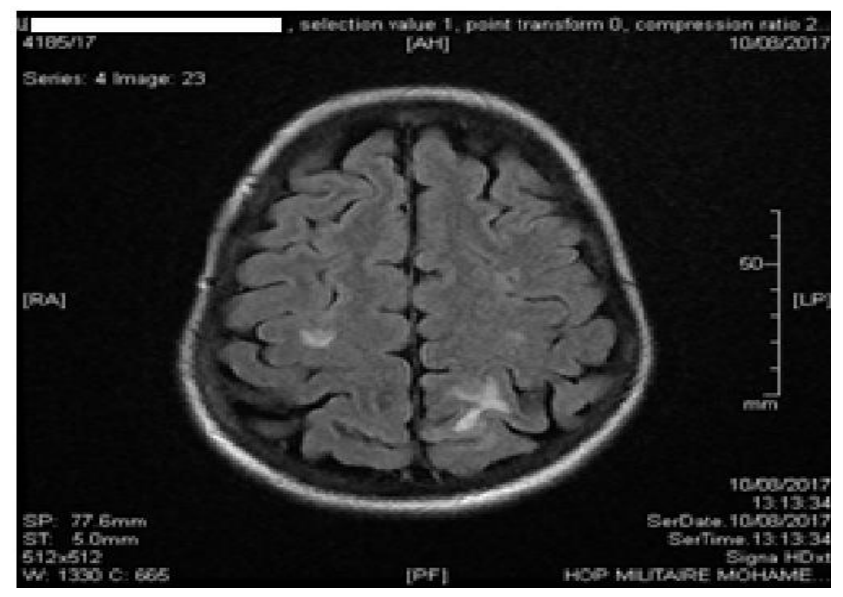

Figure 4: Brain MRI, axial section, FLAIR sequence: hypersignals of subcortical white matter in right frontal and left parietal areas.
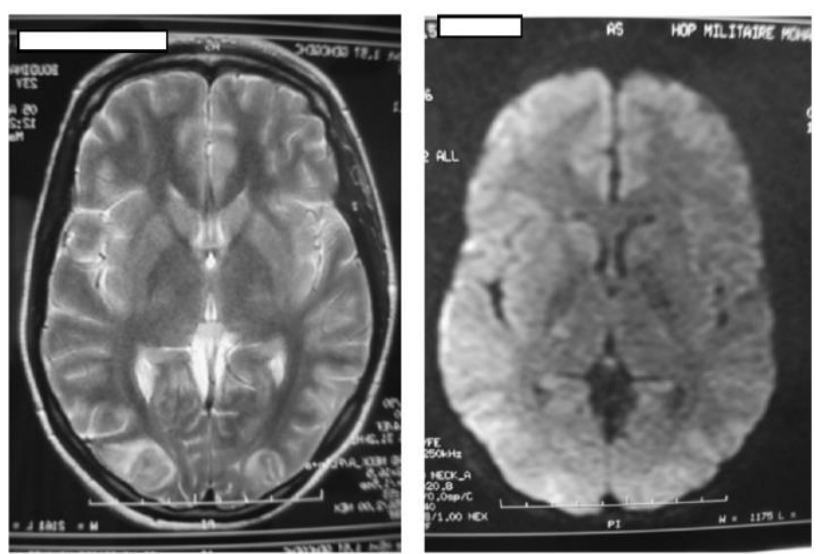

Figure 5: Brain MRI, axial sections, T2 and diffusion sequences: Cortico-subcortical hypersignals at bilateral occipital area, more marked on the right. 
Table 1: The clinical, paraclinical, therapeutic and evolutionary aspects in the PRES patients.

\begin{tabular}{|c|c|c|c|c|c|c|}
\hline Variables & Patient 1 & Patient 2 & Patient 3 & Patient 4 & Patient 5 & Patient 6 \\
\hline Age (years) & 23 & 31 & 25 & 26 & 28 & 29 \\
\hline Gestity & Primigest & Third gest & Primi gest & Primi gest & Primi gest & Primi gest \\
\hline Parity & Primiparous & Multiparous & Nulliparous & Primiparous & Primiparous & Nulliparous \\
\hline $\begin{array}{l}\text { Medical } \\
\text { history }\end{array}$ & None & None & $\begin{array}{l}\text { Appendicectomy } \\
8 \text { years } \\
\text { ago }\end{array}$ & None & None & None \\
\hline $\begin{array}{l}\text { Pregnancy } \\
\text { term }(A W)\end{array}$ & $\begin{array}{l}38 \mathrm{AW}+2 \\
\text { days }\end{array}$ & $\begin{array}{l}38 \mathrm{AW}+5 \\
\text { days }\end{array}$ & $27 \mathrm{AW}$ & $36 \mathrm{AW}$ & $37 \mathrm{AW}$ & $33 \mathrm{AW}$ \\
\hline $\begin{array}{l}\text { Evolution of } \\
\text { pregnancy }\end{array}$ & $\begin{array}{l}\text { Threat } \\
\text { premature } \\
\text { labor due to } \\
\text { urinary } \\
\text { infection à } 34 \\
\text { AW }\end{array}$ & Normal & Normal & $\begin{array}{l}\text {-Gemelar } \\
\text { pregnancy } \\
\text {-High BP at } \\
34 \text { AW } \\
\text { without } \\
\text { proteinuria } \\
\text { treated by } \\
\text { alpha- } \\
\text { methyldopa }\end{array}$ & $\begin{array}{l}\text { Membranes } \\
\text { premature } \\
\text { rupture at } 37 \\
\text { AW }\end{array}$ & $\begin{array}{l}\text {-Contractions at } \\
33 \text { AW } \\
\text {-Severe fetal } \\
\text { growth } \\
\text { restriction + } \\
\text { oligo- } \\
\text { hydramnios }\end{array}$ \\
\hline Proteinuria & Negative & ++ & +++ & +++ & Negative & +++ \\
\hline Edema & $\begin{array}{l}\text { Discreet lower } \\
\text { limbs edema }\end{array}$ & $\begin{array}{l}\text { Discreet } \\
\text { lower limbs } \\
\text { edema }\end{array}$ & $\begin{array}{l}\text { Discreet lower } \\
\text { limbs edema }\end{array}$ & $\begin{array}{l}\text { Lower limbs } \\
\text { edema }\end{array}$ & None & $\begin{array}{l}\text { Discreet lower } \\
\text { limbs edema }\end{array}$ \\
\hline $\begin{array}{l}\text { Blood } \\
\text { pressure BP } \\
(\mathrm{mmHg})\end{array}$ & $140 / 85$ & $180 / 100$ & $167 / 110$ & $174 / 100$ & $140 / 90$ & $180 / 110$ \\
\hline Headaches & $\begin{array}{l}\text { Helmet-like } \\
\text { headaches }\end{array}$ & $\begin{array}{l}\text { Intense } \\
\text { helmet-like } \\
\text { headaches }\end{array}$ & $\begin{array}{l}\text { Invalidant } \\
\text { helmet-like } \\
\text { headaches }\end{array}$ & $\begin{array}{l}\text { Intense } \\
\text { headaches }\end{array}$ & $\begin{array}{l}\text { Intense } \\
\text { helmet-like } \\
\text { headaches }\end{array}$ & $\begin{array}{l}\text { Helmet-like } \\
\text { headaches }\end{array}$ \\
\hline $\begin{array}{l}\text { Headaches } \\
\text { onset of the } \\
\text { time }\end{array}$ & $\begin{array}{l}\text { Postpartum } 7^{\text {th }} \\
\text { day }\end{array}$ & $\begin{array}{l}\text { Post-partum } \\
12^{\text {th }} \text { hour }\end{array}$ & $27 \mathrm{AW}$ & $36 \mathrm{AW}$ & $\begin{array}{l}\text { Postpartum } \\
7^{\text {th }} \text { day }\end{array}$ & $33 \mathrm{AW}$ \\
\hline $\begin{array}{l}\text { Convulsive } \\
\text { seizures }\end{array}$ & $\begin{array}{l}\text { Generalized } \\
\text { convulsive } \\
\text { seizures }\end{array}$ & $\begin{array}{l}3 \text { tonic-clonic } \\
\text { generalized } \\
\text { seizures }\end{array}$ & $\begin{array}{l}2 \text { generalized } \\
\text { convulsive } \\
\text { seizures }\end{array}$ & $\begin{array}{l}\text { Many tonic- } \\
\text { clonic } \\
\text { generalized } \\
\text { seizures }\end{array}$ & $\begin{array}{l}\text { Tonic-clonic } \\
\text { generalized } \\
\text { seizures }\end{array}$ & $\begin{array}{l}\text { Tonic-clonic } \\
\text { generalized } \\
\text { seizures } \\
\text { followed by } \\
\text { convulsive state }\end{array}$ \\
\hline $\begin{array}{l}\text { Seizures on } \\
\text { set time }\end{array}$ & $\begin{array}{l}\text { Postpartum } 7^{\text {th }} \\
\text { day }\end{array}$ & $\begin{array}{l}\text { Postpartum } \\
12^{\text {th }} \text { hour }\end{array}$ & $\begin{array}{l}27 \text { AW (many } \\
\text { hours after } \\
\text { headaches) }\end{array}$ & $\begin{array}{l}\text { Postpatum } \\
11^{\text {th }} \text { hour }\end{array}$ & $\begin{array}{l}\text { Postpartum } \\
7^{\text {th }} \text { day }\end{array}$ & $33 \mathrm{AW}$ \\
\hline $\begin{array}{l}\text { Blood } \\
\text { pressure } \\
\text { during } \\
\text { seizures } \\
(\mathrm{mmHg})\end{array}$ & $180 / 100$ & $140 / 90$ & $180 / 110$ & $150 / 90$ & $230 / 120$ & $210 / 110$ \\
\hline $\begin{array}{l}\text { Other } \\
\text { clinical signs }\end{array}$ & $\begin{array}{l}\text { Vertigo } \\
\text { Dyspnea }\end{array}$ & Nil & $\begin{array}{l}\text { Bilateral } \\
\text { hemianopsia } \\
\text { with vivid } \\
\text { osteotendinous } \\
\text { reflexes, } \\
\text { Nausea }\end{array}$ & Nil & Vertigo & $\begin{array}{l}\text {-Tinnitus } \\
\text {-Consciousness } \\
\text { disorders }\end{array}$ \\
\hline Complication & $\begin{array}{l}\text { Acute lung } \\
\text { edema }\end{array}$ & $\begin{array}{l}\text {-HELLP } \\
\text { syndrome } \\
\text {-Eclampsia }\end{array}$ & -Eclampsia & -Eclampsia & Nil & $\begin{array}{l}\text { Oligohydramnios } \\
\text {-Eclampsia } \\
\text {-Convulsive } \\
\text { State }\end{array}$ \\
\hline $\begin{array}{l}\text { Brain CT } \\
\text { scan }\end{array}$ & Normal & & & & Normal & \\
\hline
\end{tabular}




\begin{tabular}{|c|c|c|c|c|c|c|}
\hline Variables & Patient 1 & Patient 2 & Patient 3 & Patient 4 & Patient 5 & Patient 6 \\
\hline Brain MRI & $\begin{array}{l}\text { Hypersignals } \\
\text { of subcortical } \\
\text { white matter } \\
\text { at frontal and } \\
\text { bilateral } \\
\text { parietal level. } \\
\text { Figure } 1 \mathrm{~A}\end{array}$ & $\begin{array}{l}\text { Bilateral and } \\
\text { asymmetric } \\
\text { cortico- } \\
\text { subcortical } \\
\text { hypersignals, } \\
\text { in parieto- } \\
\text { occipital area. } \\
\text { Figure } 2 \text { A }\end{array}$ & $\begin{array}{l}\text { Bilateral and } \\
\text { asymmetric } \\
\text { cortico- } \\
\text { subcortical } \\
\text { hypersignals, in } \\
\text { parietal, } \\
\text { capsulo- } \\
\text { lenticulars and } \\
\text { caudate nuclei } \\
\text { heads areas. } \\
\text { Figure } 3\end{array}$ & $\begin{array}{l}\text { Hypersignals } \\
\text { of subcortical } \\
\text { white matter } \\
\text { in right frontal } \\
\text { and left } \\
\text { parietal area. } \\
\text { Figure } 4\end{array}$ & $\begin{array}{l}\text { Cortico- } \\
\text { subcortical } \\
\text { hypersignals } \\
\text { at bilateral } \\
\text { occipital } \\
\text { area, more } \\
\text { marked on } \\
\text { the right. } \\
\text { Figure } 5\end{array}$ & $\begin{array}{l}\text { Bilateral } \\
\text { posterior parietal } \\
\text { hypersignals. }\end{array}$ \\
\hline EEG & $\begin{array}{l}\text { Diffuse } \\
\text { paroxysmal } \\
\text { activity for } \\
\text { short time. } \\
\text { Figure 1 B }\end{array}$ & Normal & & & $\begin{array}{l}\text { Neurological } \\
\text { distress signs }\end{array}$ & \\
\hline $\begin{array}{l}\text { Other } \\
\text { analysis }\end{array}$ & $\begin{array}{l}\text { Brain } \\
\text { natriuretic } \\
\text { protein at } 457 \\
\text { pg/ml }\end{array}$ & $\begin{array}{l}\text { HELLP } \\
\text { syndrome }\end{array}$ & Normal & Normal & Normal & Normal \\
\hline Delivery & $\begin{array}{l}\text { Caesarean } \\
\text { section for } \\
\text { dynamic } \\
\text { dystocia }\end{array}$ & $\begin{array}{l}\text { Prophylactic } \\
\text { caesarean } \\
\text { section for } \\
\text { surgical } \\
\text { pelvis }\end{array}$ & $\begin{array}{l}\text { Caesarean } \\
\text { section for } \\
\text { eclampsia }\end{array}$ & $\begin{array}{l}\text { CS for } 1^{\text {st }} \text { twin } \\
\text { breech } \\
\text { presentation } \\
\text { and dynamic } \\
\text { dystocia }\end{array}$ & $\begin{array}{l}\text { Caesarean } \\
\text { section for } \\
\text { dynamic } \\
\text { dystocia }\end{array}$ & $\begin{array}{l}\text { Caesarean } \\
\text { section for } \\
\text { eclampsia }\end{array}$ \\
\hline Treatment & $\begin{array}{l}\text {-Midazolam, } \\
\text {-Phenobarbital } \\
\text {-Sodium } \\
\text { valproat } \\
\text {-Magnesium } \\
\text { sulfate } \\
\text {-Furosemid }\end{array}$ & $\begin{array}{l}\text {-Diazepam, } \\
\text { Phenobarbital } \\
\text { - Nicardipin }\end{array}$ & $\begin{array}{l}\text {-Midazolam } \\
\text {-Nicardipin } \\
\text {-Alpha- } \\
\text { methyldopa } \\
\text {-Magnesium } \\
\text { sulfate } \\
\text {-Corticosteroids }\end{array}$ & $\begin{array}{l}\text {-Diazepam } \\
\text {-Magnesium } \\
\text { sulfate } \\
\text {-Alpha- } \\
\text { methyldopa }\end{array}$ & $\begin{array}{l}\text {-Diazepam } \\
\text {-Nicardipin }\end{array}$ & $\begin{array}{l}\text {-Diazepam } \\
\text {-Magnesium } \\
\text { sulfate } \\
\text {-Nicardipin }\end{array}$ \\
\hline $\begin{array}{l}\text { Exit } \\
\text { prescription }\end{array}$ & $\begin{array}{l}\text {-Sodium } \\
\text { valproate } \\
\text {-Heparin }\end{array}$ & $\begin{array}{l}\text {-Sodium } \\
\text { valproate } \\
\text {-Heparin }\end{array}$ & $\begin{array}{l}\text {-Sodium } \\
\text { valproate } \\
\text {-Heparin } \\
\text {-Alpha-methyl } \\
\text { dopa }\end{array}$ & $\begin{array}{l}\text {-Sodium } \\
\text { valproate } \\
\text {-Acetyl } \\
\text { salicylic acid } \\
\text {-Alpha-methyl } \\
\text { dopa }\end{array}$ & $\begin{array}{l}\text {-Sodium } \\
\text { valproate } \\
\text {-Acetyl } \\
\text { salicylic acid }\end{array}$ & $\begin{array}{l}\text {-Acetyl salicylic } \\
\text { acid }\end{array}$ \\
\hline Evolution & $\begin{array}{l}\text { Complete } \\
\text { symptoms } \\
\text { disappearance. }\end{array}$ & $\begin{array}{l}\text { Normalization } \\
\text { of blood } \\
\text { pressure and } \\
\text { biological } \\
\text { assessment, } \\
\text { return to } \\
\text { initial } \\
\text { neurological } \\
\text { state }\end{array}$ & $\begin{array}{l}\text { Blood pressure } \\
\text { normalization } \\
\text { and neurological } \\
\text { signs } \\
\text { improvment. }\end{array}$ & $\begin{array}{l}\text { Blood } \\
\text { pressure } \\
\text { normalization } \\
\text { and seizures } \\
\text { disappearance. }\end{array}$ & $\begin{array}{l}\text { Satisfying } \\
\text { clinical } \\
\text { evolution }\end{array}$ & $\begin{array}{l}\text { Clinical signs } \\
\text { improvment }\end{array}$ \\
\hline Control & $\begin{array}{l}\text { Clinical and } \\
\text { radiological } \\
\text { control at } 9 \\
\text { weeks is } \\
\text { without } \\
\text { abnormalities. }\end{array}$ & $\begin{array}{l}2 \text { months } \\
\text { check-up: no } \\
\text { clinical } \\
\text { anomaly. } \\
\text { Control MRI: } \\
\text { complete } \\
\text { brain damage } \\
\text { resolution. } \\
\text { Figure } 2 \text { B }\end{array}$ & $\begin{array}{l}\text { Control at } \\
\text { postpartum } \\
\text { second month: } \\
\text { normal clinical } \\
\text { examination and } \\
\text { control brain } \\
\text { MRI showed } \\
\text { disappearance of } \\
\text { radiological } \\
\text { lesions. }\end{array}$ & $\begin{array}{l}\text { Control at } \\
\text { postpartum } \\
45^{\text {th }} \text { day; } \\
\text { normal } \\
\text { clinical exam. } \\
\text { radiological } \\
\text { brain MRI } \\
\text { control } \\
\text { showed } \\
\text { disappearance } \\
\text { of radiological } \\
\text { lesions. }\end{array}$ & $\begin{array}{l}3 \text { months } \\
\text { check-up: no } \\
\text { clinical } \\
\text { anomaly. }\end{array}$ & $\begin{array}{l}3^{\text {rd }} \text { week check- } \\
\text { up: no clinical } \\
\text { anomaly. Brain } \\
\text { MRI control: } \\
\text { complete brain } \\
\text { damage } \\
\text { resolution. }\end{array}$ \\
\hline
\end{tabular}




\begin{tabular}{|c|c|c|c|c|c|c|}
\hline Variables & Patient 1 & Patient 2 & Patient 3 & Patient 4 & Patient 5 & Patient 6 \\
\hline Newborn & $\begin{array}{l}\text {-Apgar 10/10 } \\
\text {-3100 g } \\
\text {-Alive }\end{array}$ & $\begin{array}{l}\text {-Apgar 10/10 } \\
\text {-2900 g } \\
\text {-Alive }\end{array}$ & $\begin{array}{l}\text {-Apgar 08/10 } \\
\text {-950g } \\
\text {-Neonatal } \\
\text { intensive care } \\
\text { hospitalization } \\
\text { for } 65 \text { days }\end{array}$ & $\begin{array}{l}\text {-Apgar 10/10 } \\
-2550 \text { and } \\
2400 \mathrm{~g} \\
\text {-alives }\end{array}$ & -Apgar 10/10 & $\begin{array}{l}\text {-Apgar } 4 / 10 \\
-1050 \mathrm{~g} \\
\text {-Died after } 3 \\
\text { hours }\end{array}$ \\
\hline
\end{tabular}

\section{DISCUSSION}

PRES actual impact is still unclear. Besides, there is no information about PRES incidence in peripartum. ${ }^{1}$ Average age of PRES onset is around 45 years, it is less common in men than women. ${ }^{2}$ Average age in three Moroccan series is around 29 years old. ${ }^{3}$ Our patients are between 23 and 31 years old, with an average of $27 \pm 1.56$ years. PRES can occur in much younger women; 21.4 years old as average age in Cunningham series, 21.8 years old in Brewer series and 20 years old in Loureiro series. ${ }^{3-5}$

PRES is more common in primigravida. ${ }^{3}$ In our study, 5 patients $(83.33 \%)$ were primiparous. Our patients' average term was 35 amenorrhea weeks (AW) with extremes of 27 AW and 38 AW and 5 days. There is not much difference with Araqi-Houssaini et al, Harandou et al and Brewer et al studies. ${ }^{4,6,7}$

In obstetrics, the majority of PRES cases are due to preeclampsia with $66.67 \%$ of cases in our series, or to one of its complications, specifically eclampsia, with $66.67 \%$ in our series or even less HELLP syndrome, with $16.67 \%$ in our series. In Zeeman's study, out of 27 eclampsia, 15 had developed PRES (55.5\%). ${ }^{8}$ In addition, the AraqiHoussaini et al study focused on 298 cases of eclampsia, from which 89 images are showing PRES lesions in 13 cases $(14.6 \%){ }^{6}$

In Brewer study, PRES occur in $50 \%$ of patients in prepartum, $76 \%$ of cases in Loureiro study and $61.5 \%$ of cases in Araqi-Houssaini et al study. ${ }^{4-6}$ In our series, PRES occurred in prepartum in 2 out of 6 patients (33.33\%). This could be explained by the fact that most eclampsia occurs during pregnancy or childbirth.

In postpartum, PRES occurs in 2/3 of cases within the first week after childbirth. ${ }^{4}$ In our series, $6 / 6$ of patients (100\%) with PRES did not go beyond the first week of postpartum. This can sometimes happen later. However, PRES can occur during childbirth and immediate postpartum, favored by vasoactive drugs used in epidural anesthesia, postpartum hemorrhage and inhibition of lactation. ${ }^{9}$

Neurological manifestations occur suddenly, they are various and frequently include convulsion seizures, headaches, confusion, nausea and vomiting. These manifestations can lead to coma. ${ }^{10}$
Classically, headaches set in progressively, often isolated, bilateral and starting in posterior areas before becoming diffuse. ${ }^{11}$ Thunderclap headaches are also possible. ${ }^{6,11}$ All our patients $(100 \%)$ presented severe "helmet-like" headaches.

Seizures are reported in $92 \%$ of cases, most often generalized. ${ }^{10}$ In our series, 6 patients $(100 \%)$ presented generalized tonic-clonic seizures. A status epilepticus is also possible, as presented by one of our patients $(16.67 \%)^{12}$

Visual disturbances are present in more than $50 \%$ of cases. They vary from simple visual blurring to total cortical blindness, including hemianopsia. ${ }^{13}$ In our series, one of our patients presented a bilateral hemianopsia (16.67\%).

High blood pressure occurs during headache attacks. Thus, about a third of patients have high blood pressure during painful headache episodes. ${ }^{10,12,13}$ All patients in our series had high blood pressure. The 4 patients $(66.67 \%)$ presented a hypertension peak ranging from 167 $\mathrm{mmHg} / 110 \mathrm{mmHg}$ to $180 \mathrm{mmHg} / 110 \mathrm{mmHg}$ on admission or at delivery. during seizures, 4 patients presented hypertensive peaks ranging from 180/100 $\mathrm{mmHg}$ to $230 / 120 \mathrm{mmHg}$.

Other neurological manifestations such as psychomotor slowing, confusion, lethargic state and agitation have been reported. ${ }^{13}$ Two of our patients presented vertigo $(33.33 \%)$, another presented consciousness troubles $(16.67 \%)$.

There are also severe forms with hemorrhage or massive edema in posterior fossa, leading to hydrocephalus or brainstem compression. Finally, focal deficit signs can also exist such as hemiparesis or aphasia. ${ }^{12}$

In retrospective studies, brain computed tomography (CT) is performed in a high number of patients $(65 \%$ to $100 \%) \cdot{ }^{10,14}$ Examination is generally normal or shows nonspecific abnormalities in $66 \%$ of cases. ${ }^{14}$ Lesions could appear as hypodensities of evocative topography which do not take contrast. Edema may be visible on CT scan but with imperfect sensitivity. Scanner is not a performant examination for diagnosis because it is falsely reassuring in $40 \%$ of cases. Brain CT was performed in 2 patients in series $(33.33 \%)$ showing no abnormalities. 
Brain MRI is the gold standard for both diagnosis and monitoring of PRES, it provides images with very high resolution, and detect invisible small focal lesions on CT scan. ${ }^{15}$ The most commonly observed anomaly is cerebral edema without infarction, typically affecting subcortical white matter in posterior areas of cerebral hemispheres bilaterally and symmetrically, for the most part, in parietaloccipital regions. ${ }^{3}$ Brainstem and cerebellum injuries are frequent, while frontal lobe damage is rare, with T1 hyposignal, T2 and Fluid-attenuated inversion recovery (FLAIR) hypersignal appearance. There is usually no enhancement after injection of contrast product. ${ }^{16}$ MRI in diffusion sequence is the best diagnosis tool allowing an adapted and rapid treatment in order to prevent appearance of irreversible neurological lesions and permanent sequelae. Brain MRI was performed in $6 / 6$ patients $(100 \%)$, it showed bilateral subcortical foci, T1 hypointense appearance, T2 and FLAIR hypersignal in all patients $(100 \%)$. Brain lesions predominate parietal and occipital posterior territories (6/6 cases) $(100 \%)$, then in frontal areas (2/6 cases) $(33.33 \%)$.

Angiography reveals vascular anomalies with focal and diffuse vasodilation and vasoconstrictions, generally causing a "pearl necklace-like" appearance, even in the absence of significant high blood pressure. However, it may be normal when it is done early. Other brain imaging techniques can be used such as proton magnetic resonance spectroscopy, brain scintigraphy/single-photon emission computed tomography (SPECT), apparent diffusion coefficient mapping (ADC) and 3D MRI angiography.

Diagnosis of PRES, as its name suggests, can only be made after a reversibility proof, by vascular imaging at three months (CT, MRI or arteriography) showing a return to normal/ at least a clear regression of vascular involvement.

Biology does not contribute to PRES positive diagnosis. ${ }^{9}$ Lumbar puncture is almost systematic, in order to eliminate subarachnoid hemorrhage if brain CT scan is normal. ${ }^{17}$ Biological assessment carried out in our patients, showing a significant proteinuria in 4 of them $(66.67 \%), 1$ patient presented HELLP syndrome (16.67\%).

Electroencephalogram (EEG) usually shows slow and unresponsive traces with no focalization signs. ${ }^{18}$ EEG was performed in 3 of our patients $(50 \%)$, objectifying signs of neurological suffering in 2 patients $(66.66 \%)$.

Both etiology and clinical presentation of PRES will determine therapeutic strategy. Stopping the triggering or aggravating factor is the first therapeutic measure. ${ }^{7}$ there is no standardized therapy guidelines. ${ }^{19}$ In fact, many treatments have been detailed, with very different and sometimes opposing outcomes. ${ }^{20}$ However, controlling hypertension is the crucial part of management. It uses habitual antihypertensive agents: calcium channel blockers (nicardipin and diltiazem), beta blockers (labetolol) and diuretics. The objective is to maintain an average arterial pressure between 105 and $125 \mathrm{mmHg}$, without reducing this pressure more than $25 \%$ during first hour. Magnesium sulfate has a vasodilator effect, which increases blood flow to the brain, serving to prevent ischemic damage that causes seizures. ${ }^{21}$ Corticosteroids are the most commonly used drugs against vasospasm and headaches. Association of anti-edematous treatment, mannitol in this case, should be discussed on case-by-case basis and may only be beneficial in a number of situations. ${ }^{7}$ However, spontaneous regression of PRES makes the assessment of treatments efficacy difficult. Moreover, hypertension treatment should be careful because hypotension should not be induced when there is already a cerebral vasospasm reducing cerebral flow. In the occurrence of a seizure, antiepileptic treatment must be started urgently. Benzodiazepines should be administered as first line treatment. ${ }^{22}$

From a therapeutic perspective, our patients benefited from symptomatic treatment as follows: 1) anticonvulsant treatment: all patients $(100 \%)$ received benzodiazepines (diazepam $4 / 6$ or midazolam 2/6) in acute phase. Magnesium sulfate was administered in $4 / 6$ of cases $(66.67 \%)$. Sodium valproate and Phenobarbital were respectively received in $1 / 6$ cases (16.67\%). 2) antihypertensive treatment: in acute phase, $5 / 6$ patients $(83.33 \%)$ received antihypertensive monotherapy, one patient received bi-therapy (16.67\%). As intensive care measures, patient who presented acute lung edema received non-invasive ventilation. Fluid-electrolyte rebalance, blood and platelet concentrates transfusion were administered to patient with HELLP syndrome. Fetal extraction as etiological treatment was carried out in 2 patients with prepartum eclampsia (100\%).

One of PRES specific features is reversibility. Correct and early diagnosis and treatment of PRES can prevent neurological irreversible lesions. ${ }^{23}$ Despite severity of initial clinical presentation (coma, status epilepticus), evolution is usually favorable, subject to early and appropriate management. ${ }^{19}$ In the majority of cases, a complete regression of clinical and radiological abnormalities is observed within few days or even few weeks. ${ }^{13}$ Nevertheless, normalization is sometimes only obtained after one year. It should be emphasized that lack of early treatment can lead to clinical aggravation. ${ }^{23}$ PRES, because of its relatively recent description, has not yet been subject of prolonged longitudinal studies; clinical evolution of patients after regression is therefore very poorly understood.

In our series, clinical, biological and radiological evolution was favorable in $6 / 6$ patients $(100 \%)$. It was marked by complete clinical remission without recurrence. A control brain MRI was performed in all our patients, demonstrating a complete resolution of lesions, confirming PRES diagnosis.

Several cases of death during PRES have been described. ${ }^{24}$ $30.7 \%$ in Araqi-Houssaini et al series and 30\% in Salami et al series. ${ }^{6,25}$ In our series, there were no deaths. 
In our series, stillbirth rate did not exceed $15 \%(1 / 7$ newborns died after third hour birth). While in AraqiHoussaini et al study, stillbirth rate is $6 / 13(46 \%){ }^{6}$

\section{CONCLUSION}

PRES is a poorly understood phenomenon. It is a neurological entity that can occur in peripartum, regardless of any pre-existing pathology. This syndrome should be correctly and quickly identified by clinicians and specifically radiologists, in order to prevent complications which can sometimes be extremely serious. Primary therapeutic action consists on eliminate a possible triggering or aggravating factor and initiate antihypertensive and anticonvulsant treatments. However, in some severe forms, reversibility is not always assured, in spite of a timely diagnosis and consequent therapy.

\section{Funding: No funding sources}

Conflict of interest: None declared

Ethical approval: Not required

\section{REFERENCES}

1. Etesse B, Letouzey V, Roger C, Lefauconnier A, Ripart J. L'anesthésie péridurale n'est pas la seule cause de troubles neurologiques centraux durant le travail obstétrical. Un cas de syndrome d'encéphalopathie postérieure réversible. Anna Françaises d'Anesthésie et de Réanimation. 2011;30:57-60.

2. Ducros A. Réversible cérébral vasoconstriction syndrome. Lancet Neurol. 2012;11:906-17.

3. Cunningham FG, Twickler D. Cerebral edema complicating eclampsia. Am J Obstet Gynecol. 2000;182:94-100.

4. Brewer J, Martin J, Armstrong A. Eclampsia and posterior reversible encephalopathy syndrome (PRES): cause or effect or both in 47 patients? Am J Obstetr Gynecol. 2012;206:342.

5. Loureiro R, Leite CC, Kahhale S. Diffusion imaging may predict reversible brainlesions in eclampsia and severe preeclampsia: initial experience. Am J Obstet Gynecol. 2003;189:1350-5.

6. Araqi-Houssaini A, Salmi S, Moussaid I, Guennoun MA, Elyoussoufi S, Miguil M et al. Syndrome d'encéphalopathie postérieure réversible et éclampsie: étude descriptive de 13 cas au Maroc. Revue neurologique. 2011;167:812-9.

7. Harandou M, Madani N, Labibe S, Messouak O, Boujraf S, Benkirane S et al. Apport de l'imagerie neurologique chez les éclamptiques encore symptomatiques après 24 heures: étude descriptive à propos de 19 cas. Ann françaises d'anesthésie et de réanimation. 2006;25(6):577-83.

8. Zeeman G, Fleckenstein JL, Twickler DM, Cunningham FG. Cerebral infarction in eclampsia. Am J Obstetr Gynecol. 2004;190:714-20.

9. Marrone LC, Gadonski G, Diogo LP, Brunelli JPF, Martins WA, Laguna GDO et al. Posterior reversible encephalopathy syndrome: differences between pregnant and non-pregnant patients. Neurol Int. 2014;6(1):5376.

10. Sharma S, Bagga R, Modi M. Paraparesis with complete recovery in antepartum eclampsia. Int $\mathrm{J}$ Gynecol Obstetr. 2006;93:242-3.

11. Sibai BM, Spinnato JA, Watson DL, Lewis JA, Garland D, Anderson GD. Eclampsia. IV. Neurological findings and future outcome. Am J Obstet Gynecol. 1985;152:184-92.

12. Kozak OS, Wijdicks EF, Manno EM, Miley JT, Rabinstein AA. Status epilepticus as initial manifestation of posterior reversible encephalopathy syndrome. Neurology. 2007;69:894-7.

13. Cruz-Flores S, De Assis Aquino Gondim F, Leira EC. Brainstem involvement in hypertensive encephalopathy: clinical and radiological findings. Neurology. 2004;62:1417-9.

14. Bartynski WS, Boardman JF, Zeigler ZR, Shadduck RK, Lister J. Posterior reversible encephalopathy syndrome in infection, sepsis, and shock. AJNR Am J Neuroradiol. 2006;27:2179-90.

15. Sengar AR, Gupta R, Dhanuka A, Roy R, Das K. MR imaging, MR angiography, and MR spectroscopy of the brain in eclampsia. AJNR Am J Neuroradiol. 1997; 18:1485-90.

16. Mukherjee P, McKinstry RC. Reversible posterior leukoencephalopathy syndrome: evaluation with diffusion-tensor MR imaging. Radiology. 2001;219:756-65.

17. Papoutsis D, El-Attabi N, Sizer A. Postpartum posterior reversible encephalopathy syndrome (PRES) in a twin pregnancy complicated by preeclampsia-eclampsia: case report. Clin Exp Obstet Gynecol. 2014;41(3):351-3.

18. Natsume J, Sofue A, Yamada A, Kato K. Electroencephalographic (EEG) findings in posterior reversible encephalopathy associated with immunosuppressants. J. Child Neurol. 2006;21(7):620-23.

19. Maramattom BV, Zaldivar RA, Glynn SM, Eggers SD, Wijdicks EFM. Acute intermittent porphyria presenting as a diffuse encephalopathy. Ann neurol. 2005;57(4):581-4.

20. Calabrese LH, Dodick DW, Schwedt TJ, Singhal AB. Narrative review: reversible cerebral vasoconstriction syndromes. Ann Intern Med. 2007;146(1):34-44.

21. Lee VH, Wijdicks EF, Manno EM. Clinical spectrum of reversible posterior leukoencephalopathy syndrome. Arch Neurol. 2008;65:205-10.

22. Sigurta A, Terzi V, Regna-Gladin C, Fumagalli R. Posterior Reversible Encephalopathy Syndrome Complicating Traumatic Pancreatitis. Medicine. 2016;95(22):e3758.

23. Digre KB, Varner MW, Osborn AG. Cranial magnetic resonance imaging in severe preeclampsia vs eclampsia. Arch Neurol. 1993;50(4):399-406.

24. Solinas C, Briellmann RS, Harvey AS, Mitchell LA, Berkovic SF. Hypertensive encephalopathy. 
Antecedent to hippocampal sclerosis and temporal lobe epilepsy? Neurology. 2003;60(9):1534-6.

25. Salmi S, El youssoufi S, Araqi-houssaini A. La leucoencéphalopathie postérieure réversible au cours de l'éclampsie étude de série. Ann Françaises d'Anesthésie et de Réanimation. 2009;28:132-5.
Cite this article as: Benjilany A, Kouach J. Posterior reversible encephalopathy syndrome and pregnancy: a Moroccan retrospective study of a patient's oligo series. Int J Reprod Contracept Obstet Gynecol 2021;10:3942-9. 